\title{
BERPIKIR INTUITIF SEBAGAI SOLUSI MENGATASI RENDAHNYA PRESTASI BELAJAR MATEMATIKA
}

\author{
Sofia Sa’o \\ Program Studi Pendidikan Matematika FKIP Universitas Flores \\ Jl. Sam Ratulangi, Ende, Flores, NTT
}

\begin{abstract}
One of the factors that are important to achieve the goals of mathematics learning is a way of thinking students during learning. One of the processes used are intuitive thinking. Intuitive thinking is a cognitive process that led to the idea as a strategy for making decisions in solving problems. Spontaneous answers both written and oral expression so that students solve mathematical problems without the use of analytical thinking. The purpose of this study was to describe the solution to overcome the lack of mathematics achievement by means of intuitive thinking. The method used is qualitative to describe the solution of the subject in intuitive thinking. The subject was the four student of class VIII. Subjects using antisipatory intuitive ways of thinking that is contrary to the alleged problem solving in general and included in the global components and perception because it produces the correct answer with the solution.
\end{abstract}

Keywords: Intuitive thinking; Mathematics; Achievement

\section{PENDAHULUAN}

Dewasa ini matematika merupakan salah satu bidang studi yang mendapat perhatian cukup besar, baik dari masyarakat maupun pemerintah. Berbagai upaya telah dilakukan untuk meningkatkan mutu pendidikan, khususnya pendidikan matematika di Indonesia, oleh beberapa pihak yang peduli kepada matematika sekolah. Namun hasil belajar yang dicapai belum sesuai dengan yang diharapkan.

Berbicara tentang pembelajaran matematika di sekolah tidak terlepas dari masalahmasalah yang terdapat di dalamnya. Para guru menyadari bahwa matematika bukanlah termasuk bidang studi yang mudah bagi kebanyakan siswa. Matematika sering dikeluhkan sebagai bidang studi yang sulit dan membosankan siswa karena diajarkan dengan metode yang tidak menarik, guru menerangkan materi sementara siswanya hanya mencatat, sehingga nilai matematika siswa rendah dibanding nilai pelajaran lain.

Salah satu faktor rendahnya hasil belajar siswa, bukan semata-mata karena materi yang sulit, namun terlebih disebabkan oleh proses pembelajaran yang dilaksanakan. Hal 
ini didukung oleh hasil penelitian sebelumnya tentang kreativitas model pembelajaran matematika di SMPN 2 Ende (Sa’o, 2014).

Soedjadi (2001) menjelaskan bahwa penyebab kesulitan belajar dapat bersumber dari dalam diri siswa dan juga dari luar diri siswa. Misalkan cara penyajian materi pelajaran/suasana pembelajaran yang dilaksanakan di kelas. Lebih lanjut dikatakan bahwa betapapun tepat dan baiknya bahan ajar matematika yang diterapkan, belum menjamin akan tercapainya tujuan pendidikan matematika yang diinginkan. Salah satu faktor penting untuk mencapai tujuan pembelajaran adalah proses belajar. Kecenderungan pembelajaran matematika saat ini adalah pembelajaran yang memusat pada keterlibatan siswa secara aktif. Tetapi kenyataan di lapangan menunjukkan bahwa pembelajaran matematika yang dilakukan di sekolah-sekolah masih berjalan secara konvensional. Banyak guru matematika yang mendominasi pelajaran sehingga aktivitas siswa cenderung kurang. Hal ini tentu saja berdampak pada pencapaian hasil belajar siswa. Yuwono (2001) menyebutkan bahwa pengajaran matematika secara konvensional mengakibatkan siswa hanya bekerja secara prosedural dan memahami matematika tanpa penalaran. Selain itu salah satu keluhan yang banyak terdengar dalam dunia pendidikan matematika adalah kurangnya keterkaitan antara pembelajaran matematika di sekolah dengan dunia nyata dan kehidupan sehari-hari siswa. Untuk itu, dalam meningkatkan pembelajaran yang memberikan nuansa menyenangkan bagi siswa, serta dapat mengakrabkan matematika dengan siswa. Berkaitan dengan itu, Freundenthal (1991) mengatakan bahwa matematika adalah aktivitas manusia sehingga pembelajaran matematika dipandang sebagai suatu proses dan bukan sebagai barang jadi.

Dalam pembelajaran matematika guru dan siswa dituntut untuk berpikir. Berpikir adalah proses kognitif yang memunculkan ide untuk menyelesaikan masalah berdasarkan informasi (internal ataupun eksternal). Menurut Solso (2007), berpikir adalah proses aktif yang membentuk representasi mental baru melalui transformasi informasi oleh interaksi komplek dari atribusi mental yang mencakup pertimbangan, pengabstrakan, penalaran, penggambaran, pemecahan masalah, pembentukan konsep, kreativitas, dan kecerdasan. Proses berpikir dapat digolongkan ke dalam beberapa jenis, diantaranya berpikir analitik dan berpikir intuitif. Menurut Herdy (2007), bahwa pola berpikir manusia dalam mengembangkan ilmu pengetahuan terdapat dua cara, yaitu cara analitik yang berupa penalaran induktif dan deduktif serta cara non analitik yang berupa intuisi. Berpikir 
intuitif dapat menghasilkan hipotesis untuk mengembangkan pengetahuan selanjutnya dan untuk pembuktiannya digunakan berpikir analitik. Dalam pemecahan masalah seseorang dapat menggunakan berpikir intuitif jika menemukan kesulitan untuk diselesaikan secara analitik. Misalkan untuk menyelesaikan soal 202012 x 202010 202009 x 202013. Jika diselesaikan secara analitik membutuhkan waktu lama sedangkan secara intuitif dapat langsung mengoperasikan dua angka belakang dari setiap kelompok bilangan yang diketahui.

Rendahnya prestasi belajar siswa salah satu pemicunya adalah tidak adanya solusi yang diajarkan guru atau yang dipikirkan siswa saat mengalami kendala dalam proses pemecahan masalah. Pemecahan masalah matematika membutuhkan banyak solusi agar memperoleh hasil yang diinginkan. Salah satunya dengan cara berpikir intuitif. Terdapat 3 faktor yang mendukung munculnya berpikir intuitif pada seseorang saat mengalami kesulitan dalam pemecahan masalah yaitu: berdasarkan feeling, intrinsik, dan intervensi (Sa'o, 2014).

Feeling adalah munculnya ide dalam pikiran sebagai solusi pemecahan masalah dapat dikaitkan dengan masalah yang dihadapi sehingga membuat keputusan untuk menghasilkan jawaban spontan. Intrinsik adalah ide yang muncul dalam pikiran siswa secara tiba-tiba sebagai suatu strategi untuk membuat keputusan sehingga menghasilkan jawaban spontan dalam melakukan pemecahan masalah. Intrinsik yang terjadi masih berkaitan dengan feeling. Intervensi adalah ide yang muncul dalam pikiran siswa sudah dikaitkan dengan pengetahuan sebelumnya sebagai suatu strategi untuk membuat keputusan sehingga menghasilkan jawaban spontan dalam melakukan pemecahan masalah. Intervensi yang terjadi masih berkaitan dengan feeling.

Berpikir intuitif berarti bekerja dengan feeling dan memiliki keyakinan yang kuat untuk membuat suatu keputusan. Dalam membuat keputusan seseorang membutuhkan suatu strategi yang tepat, agar keputusan yang diambil benar-benar dapat menyelesaikan permasalahan yang dihadapi. Berpikir intuitif muncul ketika seseorang mengalami kesulitan untuk menemukan jawaban benar dalam memecahkan masalah. Menurut Kustos (2010) berpikir intuitif adalah proses kognitif melalui feeling dan persepsi. Berpikir intuitif berbeda dengan berpikir analitik. Penjelasan kebenaran suatu pernyataan dengan pembuktiannya merupakan berpikir analitik, tetapi kebenaran yang munculnya secara subjektif dan diterima secara langsung (tanpa pembuktian) merupakan berpikir 
intuitif. Lebih lanjut dikatakannya bahwa pemecahan masalah matematika hendaknya menggunakan kedua cara berpikir tersebut, agar saling melengkapi untuk mencapai tujuannya.

Dreyfus \& Eisenberg (1982) mengatakan bahwa pemahaman secara intuitif sangat diperlukan sebagai “jembatan berpikir" manakala seseorang berupaya untuk menyelesaikan masalah dan memandu menyelaraskan kondisi awal dengan tujuan. Dengan kata lain, untuk beberapa siswa pada saat menyelesaikan masalah matematika telah mengetahui atau menemukan solusi/jawaban dari suatu masalah sebelum siswa menuliskan langkah penyelesaiannya. Meskipun, pada saat mereka menemukan ide awal dalam penyelesaian masalah atau langkah apa yang paling cocok untuk menyelesaikan masalah tersebut. Munculnya ide yang datang secara seketika dan bersifat otomatis (immediate) atau muncul tiba-tiba (suddenly) merupakan karakter berpikir yang melibatkan intuisi.

Menurut Fischbein (1987), intuisi adalah proses kognitif yang spontan dan segera, berdasarkan pada skemata tertentu. Ada dua jenis intuisi yang dikategorikan oleh Fischbein yaitu intuisi untuk memahami masalah yang disebut afirmatory dan intuisi untuk menyelesaikan masalah yang disebut antisipatory. Kedua jenis intuisi ini harus berjalan dalam pemecahan masalah sehingga memperoleh hasil yang maksimal. Dalam pemecahan masalah matematika terkadang terdapat sesuatu tanpa pemikiran secara mendalam yang digunakan untuk menyelesaikannya, walaupun sesuatu tersebut belum tentu dapat dibuktikan kebenarannya. Sebagai contoh, untuk membuktikan kebenaran pernyataan matematika, awalnya siswa akan berpikir secara sepintas (spontan) cara pembuktian yang digunakan, apakah bukti langsung atau tidak langsung. Ini merupakan ciri berpikir intuitif.

Usodo (2011) mengatakan bahwa berpikir intuitif berperan penting dalam menentukan strategi pemecahan masalah matematika, karena dengan intuisi siswa mempunyai gagasan kreatif dalam memecahkan masalah matematika. Banyak siswa pandai dalam menyelesaikan soal matematika sering menggunakan cara-cara yang cerdas, sehingga memberikan jawaban yang singkat dan akurat. Gagasan kreatif ini sejalan dengan tuntutan kurikulum 2013 yang mewajibkan kreativitas siswa dalam proses pembelajaran matematika. 
Menurut Kustos (2010), pemecahan masalah yang tidak dianalisis adalah ciri berpikir intuitif. Intuisi pada setiap orang berbeda-beda. Siswa seharusnya mengandalkan intuisinya sendiri dalam proses pemecahan masalah matematika. Pemecahan masalah matematika dengan cara intuisi akan menghasilkan solusi jawaban atau cara pemecahan yang berbeda-beda dari setiap siswa. Sehingga pemecahan masalah dengan berpikir intuitif akan memiliki banyak solusi jawaban berdasarkan pada pemikiran siswa dan strategi yang digunakan untuk melakukan pemecahan masalah tersebut.

Berpikir intuitif dalam pemecahan masalah matematika sering terjadi. Namun, tidak disadari oleh guru ataupun siswa. Untuk mengkaji munculnya berpikir intuitif siswa dalam pemecahan masalah matematika, peneliti melakukan observasi awal di sekolah. Berdasarkan hasil observasi awal, ditemukan banyak siswa memberikan jawaban spontan tanpa menganalisis terlebih dahulu. Terlepas dari jawaban siswa itu benar atau salah. Namun, bagi peneliti siswa sudah menggunakan intuisinya dengan menjawab spontan. Spontan diartikan siswa menjawab secara langsung, dimana proses berpikirnya mengaitkan informasi baru dengan pengetahuan awal yang sudah tersimpan dalam memori siswa sehingga menghasilkan jawaban, tanpa harus membuktikannya. Mungkin siswa langsung menjawab dengan pemikiran yang muncul saat itu. Hal ini berdasarkan hasil wawancara dengan siswa yang bersangkutan setelah pelajaran matematika selesai. Siswa tersebut mengatakan bahwa jawaban tersebut adalah hasil pemikiran yang dikaitkan dengan pengetahuan yang pernah diperolehnya di jenjang sebelumnya.

Beberapa ahli telah meneliti tentang letak proses berpikir pada otak manusia, termasuk berpikir intuitif. Otak kiri lebih menekankan cara berpikir analitik, otak kanan lebih menekankan cara berpikir imajinatif, sedangkan otak tengah menekankan cara berpikir intuitif. Wikipedia (2014) menyebutkan bahwa otak tengah (disebut juga mesencephalon), yaitu daerah kecil dari otak yang berfungsi sebagai pusat refleks visual, pendengaran, dan motor sistem informasi. Otak tengah memutuskan bagaimana harus bertindak dalam menanggapi informasi sensorik yang diterimanya. Oleh karena itu, langkah pertama dari otak ini menentukan bagaimana orang bereaksi terhadap apa yang mereka lihat dan mereka dengar. Bagian berpikir intuitif pada otak disajikan pada Gambar 1 berikut ini: 


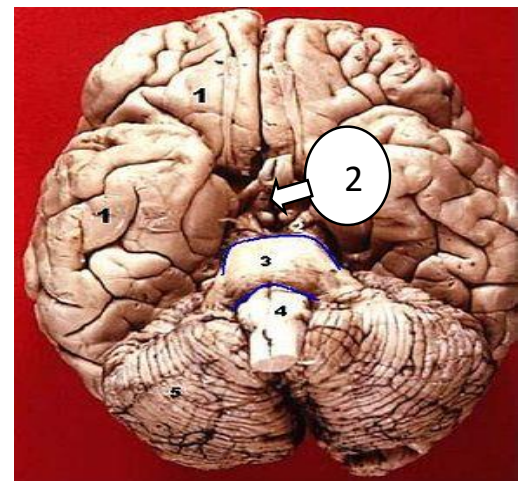

Gambar 1.

Proses intuisi ditunjukkan oleh panah nomor 2

Panah nomor 2 pada Gambar 1 menunjukkan bahwa otak tengah ukurannya sangat kecil. Namun, memiliki manfaat yang tidak kalah penting dengan fungsi otak kiri dan otak kanan. Jika suatu pertanyaan diberikan kepada seseorang, maka orang tersebut secara refleks akan menjawab apa yang ditanyakan kepadanya. Hal ini adalah cara berpikir intuitif karena orang tersebut akan menjawab sesuai dengan pikiran yang munculnya secara spontan/tiba-tiba untuk menjawab pertanyaan tersebut. Begitu pula jika ia melihat suatu objek, yang diilustrasikan pada Gambar 2. Menurut Skemp (1982), intuisi merupakan sesuatu yang pertama muncul di pikiran seseorang ketika berhadapan dengan lingkungan eksternal.

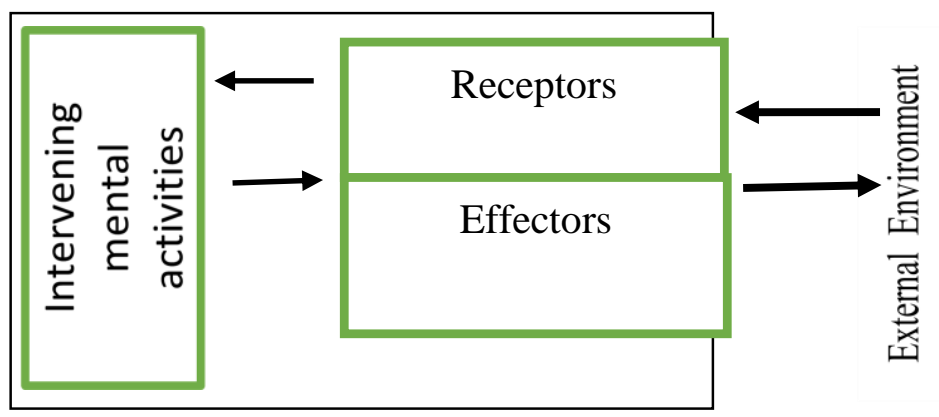

Gambar 2.

Proses berpikir intuitif

Sesuai pendapat Skemp (1982), dapat disimpulkan bahwa proses berpikir intuitif bermula dari lingkungan eksternal berupa informasi masalah yang masuk ke pikiran seseorang melalui pancaindera. Selanjutnya, diproses di otak untuk membuat solusi penyelesaian masalah. Solusi tersebut masuk ke effectors lalu kembali ke lingkungan 
eksternal berupa jawaban spontan. Intuisi yang dihasilkan oleh seseorang dapat diketahui melalui penglihatan dan pendengaran.

Berpikir intuitif sangat diperlukan jika siswa mengalami kendala dalam proses pembuktian formal atas masalah yang dihadapi. Fischbein (1987) menyebutkan berpikir intuitif dalam matematika yang paling praktis adalah ketika diberikan kasus jika $A=B$ dan $B=C$, maka $A=C$. Ini secara intuitif dapat dipahami dengan jelas. Namun, jika dibuktikan secara analisis $A, B$, dan $C$ merupakan suatu nilai dari hasil operasi aljabar. Contoh lain yang dapat diterima secara intuitif adalah himpunan bilangan asli dan himpunan bilangan positif adalah setara. Secara analitik, contoh dua himpunan setara tersebut harus menggambarkan fakta bahwa elemen-elemen dalam himpunannya memiliki kepastian dan konsisten.

Berpikir intuitif sering digunakan dalam pemecahan masalah matematika. Sebagaimana diungkapkan oleh Kustos (2010), bahwa intuisi dapat menjadi alasan pemahaman yang kuat dalam hubungannya dengan logika bukan melawan logika. Suatu pernyataan matematika memerlukan bukti, tetapi bukti dari pernyataan sering menggunakan intuisi untuk menentukan pola dalam membuktikan pernyataan tersebut. Poincare (2007) menyatakan bahwa pemecahan masalah matematika membutuhkan intuisi untuk melengkapi berpikir analitik. Dicontohkan oleh Poincare yaitu "sudut selalu dapat dibagi”. Hal ini adalah kebenaran yang dipikirkan dengan intuisi langsung. Siapa yang bisa meragukan bahwa sudut selalu dapat dibagi menjadi sejumlah bagian yang sama? Contoh lain yang dapat dipahami dengan intuisi, pada garis lurus terdapat titik $C$ yang terletak antara titik $A$ dan titik $B$ dan titik $D$ antara titik $A$ dan $C$, maka titik $D$ juga terletak antara titik $A$ dan $B$.

\section{METODE PENELITIAN}

Penelitian ini adalah penelitian deskriptif dengan pendekatan kualitatif. Dikatakan penelitian deskriptif karena untuk mendeskripsikan berpikir intuitif siswa sebagai solusi mengatasi rendahnya prestasi pelajaran matematika (Creswell, 2012). Untuk mendeskripsikan tentang proses berpikir intuitif yang digunakan siswa, maka dilakukan pemeriksaan secara teliti dan mendetail (dengan melakukan eksplorasi) terhadap subjek mengenai apa yang ditulis, diucapkan, atau bahkan apa yang dipikirkan siswa pada saat menjawab pertanyaan, menyelesaikan soal matematika, dan wawancara. Data yang 
dikumpulkan dalam penelitian ini bersifat deskriptif, meliputi data observasi dan data verbal yang diperoleh dari jawaban penyelesaian soal dan wawancara.

Langkah-langkah penelitian ini meliputi: (1) observasi awal, yaitu kegiatan yang dilakukan beriringan dengan ujicoba soal untuk memperoleh informasi kondisi siswa yang berpikir intuitif dalam menyelesaikan soal matematika. Informasi ini digunakan sebagai pertimbangan untuk menetapkan tingkat kemampuan berpikir subjek penelitian; (2) persiapan, yaitu membuat instrumen penelitian berupa soal pemecahan masalah matematika dan pedoman wawancara. Instrumen terdiri dari soal matematika dan instrumen tes kemampuan intuisi.

Subjek penelitian ini adalah siswa kelas VIII SMP yang terdiri 4 orang berdasarkan kemampuan intuisi dalam pemecahan masalah matematika. Adapun alasan pemilihan 4 siswa ini dikarenakan jawaban hampir sama dari 30 siswa yang diteliti. Subjek penelitian adalah siswa-siswa SMP dari 6 sekolah yang ada di kota Ende. Adapun kriteria pemilihan subjek adalah: (1) kemampuan matematika tinggi, informasi ini diperoleh dari guru, siswa yang memiliki kemampuan tinggi diasumsikan bahwa siswa tersebut mampu berpikir intuitif dengan baik dan (2) hasil tes kemampuan intuisi berupa 1 soal pemecahan masalah.

Proses analisis data dalam penelitian ini dilakukan dengan langkah-langkah sebagai berikut: menyiapkan dan mentranskrip data untuk dianalisis, membaca keseluruhan data, meng-coding data, menghubungkan hipotesis dengan bukti, munculnya berpikir intuitif, menyajikan data, menginterpretasikan munculnya berpikir intuitif, dan menarik kesimpulan.

\section{HASIL DAN PEMBAHASAN}

Berdasarkan uraian sebelumnya bahwa dalam penelitian ini akan diambil 1 soal yang digunakan untuk soal tes terdapat subjek penelitian agar memperoleh gambaran berpikir intuitif yang dihasilkan subjek. Berikut pembahasan tentang hasil penelitian dari 4 subjek dalam melakukan pemecahan masalah matematika. Berpikir intuitif yang terjadi merupakan solusi yang muncul pada saat siswa mengalami kesulitan untuk menyelesaikan soal matematika yang diberikan. Selanjutnya adalah pembahasan hasil pemecahan masalah oleh subjek 1 (S1), subjek 2 (S2), subjek 3 (S3), dan subjek 4 (S4). 
Pemecahan masalah yang dihasilkan oleh S1 memunculkan berpikir intuitif yang didukung oleh faktor-faktor pendukung munculnya berpikir intuitif. Berpikir intuitif muncul pada saat siswa menentukan untuk mencoret bilangan-bilangan yang sama dari keempat kelompok bilangan yang dioperasikan yaitu bilangan depan empat angka yaitu angka 2020. Selanjutnya, siswa melakukan perhitungan aljabar biasa yaitu $12 \times 10$ dikurangi $09 x 13$ sehingga memperoleh hasil 3. Dalam pemahaman masalah, S1 tidak menggunakan suatu proses tertentu, misalnya mengilustrasikan atau menggambarkan terlebih dahulu tentang apa yang dipahaminya. Namun, S1 memahami langsung masalah yang diberikan. Pemahaman secara langsung ini bukan karena S1 telah memiliki pengalaman melakukan pemecahan masalah seperti yang diberikan atau pernah membaca tulisan tentang permasalahan yang sama. Akan tetapi, dalam pemahaman masalah benarbenar diperoleh S1 sesaat setelah membaca teks masalah. Adapun jawaban S1 adalah sebagai berikut:

$$
\begin{aligned}
\text { Jawaban S1 } & =202010 \times 202012-202009 \times 202013 \\
& =120-117 \\
& =3
\end{aligned}
$$

Jika dihubungkan dengan pendapat Fischbein (1987), maka S1 menggunakan intuisi afirmatory komponen yang pertama, yaitu untuk memahami masalah digunakan kognisi langsung (self efident). Artinya, kognisi yang diterima langsung oleh individu tanpa membutuhkan pengecekan dan pembuktian lebih lanjut. Sedangkan kalau dihubungkan dengan kajian dari Kustos (2010) maka terdapat pada komponen insting. Artinya, memahami masalah dengan munculnya respon dalam berpikir terhadap masalah yang sedang dihadapi. Hal ini juga dibuktikan dengan hasil wawancara terhadap subjek dalam menjawab pertanyaan.

Berdasarkan hasil pemecahan masalah yang dilakukan oleh S1 pada jawaban sebelumnya, dapat disimpulkan bahwa S1 menggunakan cara berpikir intuitif karena S1 tidak menggunakan cara panjang dalam menghitung jawaban terlebih dahulu. Berpikir intuitif yang dimunculkan berupa ide secara tiba-tiba sebagai strategi dalam membuat keputusan berdasarkan feeling, intrinsik, dan intervensi sehingga menghasilkan jawaban pada pemecahan masalah yang dihadapi. Jika dikaitkan dengan pendapat Fischbein (1987) menggunakan intuisi antisipatory, yaitu penyelesaian masalah bertentangan dengan dugaan pada umumnya. Artinya S1 melakukan klaim suatu prosedur yang tidak 
biasa. Namun, S1 merasa klaim yang dihasilkannya itu benar. Sedangkan jika dikaitkan dengan pendapat Kustos (2010), cara yang digunakan oleh S1 ini termasuk dalam komponen persepsi dan global karena S1 menghasilkan solusi jawaban dengan benar.

Pemecahan masalah yang dihasilkan oleh S2 memunculkan berpikir intuitif yang mirip dengan S1. Berpikir intuitif muncul pada saat siswa menentukan untuk mengambil 2 angka belakang dari 4 kelompok bilangan yang diberikan dalam soal. Selanjutnya siswa melakukan perhitungan sehingga memperoleh 120 - 117 dan hasilnya sama dengan 3 . Dalam pemahaman masalah, S2 secara langsung dan dilanjutkan dengan melakukan pemecahan masalah seperti yang diberikan. Jika dihubungkan dengan pendapat Fischbein (1987) terletak pada intuisi affirmatory, yaitu untuk memahami masalah digunakan kognisi langsung (self efident). Artinya, kognisi langsung oleh individu tanpa membutuhkan pengecekan. Sedangkan jika dihubungkan dengan kajian dari Kustos (2010), maka terdapat pada komponen insting. Artinya memahami masalah dengan munculnya respon dalam berpikir terhadap masalah yang sedang dihadapi. Adapun jawaban $\mathrm{S} 2$ adalah sebagai berikut:

$$
\begin{aligned}
\text { Jawaban S2 } & =z 02010 \times Z 02012-Z 02009 \times Z 02013 \\
& =120-117 \\
& =3
\end{aligned}
$$

Berdasarkan hasil di atas, dapat disimpulkan bahwa S2 menggunakan cara berpikir intuitif. Berpikir intuitif didasarkan pada feeling, intrinsik, dan intervensi sehingga menghasilkan jawaban tanpa adanya coretan terlebih dahulu. Jika dikaitkan dengan pendapat Fischbein (1987), maka S2 menggunakan intuisi antisipatory yaitu penyelesaian masalah bertentangan dengan dugaan pada umumnya. Artinya, siswa melakukan klaim suatu prosedur yang tidak biasa. Namun, siswa merasa prosedur yang dihasilkannya itu benar. Sedangkan jika dikaitkan dengan pendapat Kustos (2010), cara yang digunakan oleh S2 ini termasuk dalam komponen persepsi dan global karena siswa melakukan persepsi terhadap solusi jawaban yang akan dihasilkan, kemudian diselesaikan sampai memperoleh hasil.

Pemecahan masalah yang dihasilkan oleh S3 memunculkan berpikir intuitif yang didukung oleh faktor-faktor pendukung munculnya berpikir intuitif. Berpikir intuitif muncul pada saat siswa memutuskan untuk mencoret 2 angka pertama dari setiap kelompok bilangan, kemudian ada lagi pikirannya setelah melihat masih terdapat dua 
angka yang sama tersisa pada setiap kelompok bilangan. Jadi, kegiatan mencoret bilangan terjadi dua kali untuk masing-masing kelompok bilangan. Selanjutnya, dilakukan perhitungan terhadap angka-angka sisa dalam setiap kelompok bilangan. Hasil yang diperoleh sama dengan hasil dari S1 dan S2. Dalam pemahaman masalah, S3 sama dengan S1 dan S2. Jika dihubungkan dengan pendapat Fischbein (1987), maka S3 menggunakan intuisi affirmatory. Artinya, untuk memahami masalah digunakan kognisi langsung (self efident). Jika dihubungkan dengan pendapat Kustos (2010), maka terdapat pada komponen insting. Artinya, memahami masalah dengan munculnya respon dalam berpikir terhadap masalah yang sedang dihadapi. Adapun jawaban S3 adalah sebagai berikut:

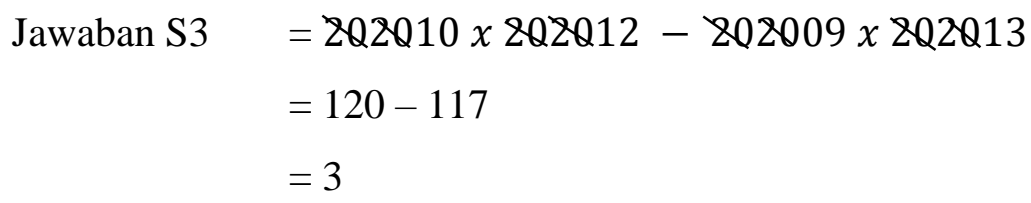

Berdasarkan hasil pemecahan masalah yang dilakukan oleh S3, dapat disimpulkan bahwa S3 menggunakan cara berpikir intuitif sehingga menghasilkan jawaban pada pemecahan dengan cara yang sesuai pada hasil jawabannya di atas. Proses berpikir yang dihasilkan pada pemecahan masalah digambarkan bahwa S3 mengikuti cara berpikir intuitif. Jika dikaitkan dengan pendapat Fischbein (1987), S3 menggunakan intuisi antisipatory yaitu penyelesaian masalah bertentangan dengan dugaan pada umumnya. Artinya, bahwa siswa melakukan klaim suatu pernyataan, cara, atau prosedur yang tidak biasa. Namun, siswa merasa klaim, cara, atau prosedur yang dihasilkannya itu benar. Sedangkan jika dihubungkan dengan pendapat Kustos (2010), cara yang digunakan oleh subjek S3 termasuk dalam komponen persepsi dan global karena siswa melakukan persepsi terhadap solusi jawaban yang akan dihasilkan, kemudian diselesaikan sampai memperoleh hasil.

Pemecahan masalah yang dihasilkan oleh S4 memunculkan berpikir intuitif pada saat siswa menentukan untuk mencoret bilangan-bilangan yang sama dari keempat kelompok bilangan yang dioperasikan. Dua angka depan yaitu angka 20. Selanjutnya, siswa menuliskan 6 bilangan sisa untuk dioperasikan. Karena masih ada bilangan yang sama kemudian dicoret lagi 2 bilangan yang sama pada setiap kelompok bilangan. Selanjutnya, dilakukan perhitungan aljabar biasa yaitu 12 x 10 dikurangi 09 x 13 sehingga memperoleh hasil 3. Adapun jawaban S4 adalah sebagai berikut: 


$$
\begin{aligned}
\text { Jawaban S4 } & =2 Q 2010 \times 2 Q 2012-8 Q 2009 \times 2 Q 2013 \\
& =2010 \times 2012-Z 009 \times 2013 \\
& =10 \times 12-9 \times 13 \\
& =120-117 \\
& =3
\end{aligned}
$$

Berdasarkan hasil pemecahan masalah yang dilakukan oleh S4, dapat disimpulkan bahwa S4 menggunakan cara berpikir intuitif. Berpikir intuitif pada pemecahan masalah yang dihadapi S4 digambarkan seperti di atas. Jika dikaitkan dengan pendapat Fischbein (1987), S4 menggunakan intuisi antisipatory yaitu penyelesaian masalah bertentangan dengan dugaan pada umumnya. Artinya, bahwa siswa melakukan klaim dan klaim yang dihasilkannya itu benar. Sedangkan jika dikaitkan dengan pendapat Kustos (2010), cara yang digunakan oleh S4 ini termasuk dalam komponen persepsi dan global karena siswa melakukan persepsi terhadap solusi jawaban yang akan dihasilkan kemudian diselesaikan sampai memperoleh hasil.

\section{SIMPULAN DAN SARAN}

Berpikir intuitif akan muncul dalam pemecahan masalah matematika jika siswa mengalami kendala dalam penyelesaian masalah. Berpikir intuitif akan muncul berdasarkan 3 faktor pendukung berpikir yang dilakukan siswa, yaitu feeling, intrinsik, dan intervensi. Proses memunculkan ide secara tiba-tiba disebut feeling yang terjadi pada pemikiran siswa. Jawaban spontan hasil dari pemikiran sesaat pada pemecahan masalah yang dihadapi oleh siswa merupakan cara berpikir intuitif karena siswa tidak menggunakan cara panjang untuk menyelesaikan soal yang diberikan dan menggunakan waktu tidak lama untuk menjawab pertanyaan saat wawancara.

Munculnya berpikir intuitif pada pemecahan masalah matematika yang dilakukan siswa merupakan solusi untuk memperoleh penyelesaian masalah dengan benar. Oleh karena itu, dapat dikatakan bahwa berpikir intuitif adalah salah satu solusi untuk mengatasi rendahnya prestasi belajar matematika.

Berdasarkan simpulan hasil penelitian ini, maka disarankan beberapa hal sebagai berikut: (1) sebaiknya guru memberikan masalah atau soal yang dapat merangsang siswa untuk berpikir intuitif, (2) melibatkan siswa menggunakan cara berpikir intuitif dengan memberikan kebebasan kepada siswa untuk melakukan pemecahan masalah. Dengan 
memberikan kebebasan berpikir, maka siswa akan melibatkan intuisinya dan membuat keputusan berdasarkan ide yang muncul dalam pikirannya untuk melakukan pemecahan masalah tersebut. Dengan demikian, guru akan memperoleh variasi cara yang diberikan oleh siswa dalam pemecahan masalah untuk memperoleh jawaban yang benar, (3) hasil penelitian ini perlu digali lebih dalam lagi. Oleh karena itu, disarankan pada peneliti lanjutan untuk mempertajam fokus penelitian, (4) dalam penelitian ini, hanya mengambil 4 subjek dengan tingkat kemampuan matematika tinggi, disarankan untuk melibatkan perbedaan tingkat kemampuan matematika siswa sebagai subjek penelitian.

\section{DAFTAR RUJUKAN}

Creswell, J. W. (2012). Designing and conducting mixed methods research. USA: Sage Publication Inc.

Dreyfus, T. \& Eisenberg, T. (1982). Intuitive functional concepts: A baseline study on intuitions. Journal for Research in Mathematics Education, 13(5), 360 - 380.

Fischbein, E. (1987). Intuition in science and mathematics an educational approach. Netherland: Reidel.

Freudenthal, H. (1991). Refisiting mathematics education china lectures. Dordrecht: Kluwer.

Hudoyo, H. (2008). Mengajar belajar matematika. Jakarta: Dirjen Dikti Depdikbud.

Kustos, P. N. (2010). Trens concerning four misconception in student's intuitively-based probabilistic reasoning sourced in the heuristic of representativeness. Diperoleh dari http://udini.proquest.com/view/trends-concerning-four.

Poincare, H. (2007). Science and hypothesis. New York: Cosimo Inc.

Moleong, L. J. (2006). Metodologi penilaian kualitatif. Bandung: Direktorat Jenderal Pendidikan Tinggi Departemen Pendidikan Nasional.

Sao, S. (2014). Berpikir intuitif dalam pembelajaran matematika. Prosiding seminar nasional TEQIP (teachers quality improvement program) membangun karakter bangsa melalui pembelajaran bermakna Universitas Negeri Malang. Malang: UM Press.

Skemp, R. R. (1982). The psychology of learning mathematics. Harmonsworth: Pinguin Books Ltd.

Soedjadi, R. (2001). Kiat pendidikan matematika di indonesia. Jakarta: Dirjen Dikti Depdikbud. 
Solso, R. L. (2007). Psikologi kognitif. Jakarta: Erlangga.

Usodo, B. (2011). Karakteristik intuisi siswa sma dalam memecahkan masalah matematika ditinjau dari kemampuan matematika dan perbedaan gender. Surakarta: Perputakaan FKIP UNS.

Voskoglu, M. G. (2006). Formalism and intuition in mathematics: The role of the problem. Italy: Quadermi di Ricerca in Didattica.

Wikipedia. (2013, Oktober 30). Intuition and decision making. Diperoleh dari http://id.wikipedia.org/wiki/intuitionanddecision-making.

Yuwono, I. (2001). Realistic mathematics education (RME) dan hasil studi awal implementasinya dan SLTP. Makalah Disajikan pada Seminar Nasional Realistic Mathematics Education (RME) di Jurusan FMIPA UNESA tanggal 24 Februari 2001. Surabaya: UNESA. 